\author{
Arūnas Molis* \\ Institute of International Relations and Political Science, University of Vilnius
}

\title{
EU Crisis Management - A Strategic Approach
}

\begin{abstract}
This article provides theoretical assumptions of crises management operations and gives a short overview of all EU civilian and military missions conducted at the end of 2007. Reasons regarding why the EU has chosen to develop their mostly civilian crises management capabilities and cooperates so closely with other international organizations in this regard, are also presented in the article. The conclusion is that the EU in its external relations tends to use similar instruments such as strengthening EU internal integration. That is why the development of civilian crises management capabilities most likely will remain faster comparing to development of military ones. Besides that, due to obvious shortages in capabilities generation process, the EU in crises management will commit itself, most often only complimenting the activities of other international organisations.
\end{abstract}

\section{Introduction}

The threat of the Soviet Union during the Cold War years was one of the engines for European integration and the creation of military aggressions among "modern" European states. On the other hand, this did not prevent the rising of regional conflicts in the Balkans at the end of the last century. A military threat against the security of Europe enhanced the integration of EU countries in the areas of foreign policy, security and defence; this gave rise to the European Neighbourhood Policy and projects on Wider Europe initiatives. Europe has created "a ring of friends" around the continent, but terrorist attacks revealed the new "truth" - that the threat of military conflicts among "modern states" was replaced with "modern threats". Terrorism, the proliferation of weapons of mass destruction, regional conflicts, failed states and organised crimes - these are the today's security challenges for Europe. In response to them, Europe has not only reinforced cooperation in the fields of internal affairs, foreign policy, security and defence, but also started implementation of crisis management operations in 2003.

Crisis management is usually understood as the application of a variety of specific political, diplomatic, economic instruments and/or measures invol-

\footnotetext{
"Arūnas Molis - is a PhD candidate, Institute of International Relations and Political Science, University of Vilnius. Address: Vokiečių 10, LT-01130 Vilnius, Lithuania, tel. +370 685 45090, e-mail: arunas. molis@gmail.com
} 
ving the employment of force in response to peace-threatening situations. Crisis management operations are aimed at the minimisation of tension, prevention of conflict escalation and contribution to such conditions that would enable the peaceful settlement of existing or pending conflicts. On a theoretical level, the systematic research in crisis management (or peace) operations sped up in 1999, when the number and effectiveness of the operations considerably increased. Writings publicised on these issues since that time may be categorised into five groups:

- Peace operations in international relations theory (Bellamy 2004, Aksu 2003);

- Case studies, including empirical studies on the effectiveness of peacekeeping (Surkhe 2001, Dobbins 2005);

- Peacekeeping and peace-building functions (Stedman 2002, Paris 2004);

- National and regional approaches to peacekeeping (Fleitz 2002, Gray 2004);

- Peace operations capacity, doctrine and reform (Durch 2003, Hansen 2002).

In this article, the theoretical premises of Bellamy, Aksu and Paris serve as the basis for explaining the motives of recently intensified EU activities in the crises management field. However, the aim of this article is more "inaugural" - to present and to analyze the most important tendencies of EU crises management activities. Therefore, referring to the primary sources (such as official information of EU Military Staff) the attention first of all is focused on a description of the last EU crises management operations, but not on their theoretical reasoning. Nevertheless, the classification of EU crises management capabilities, as well as the assessment of the EU capabilities to conduct autonomous operations, creates added value and stimulates further research in this field.

\section{Theoretical Assessment of EU Crisis Management Initiatives}

According to Bellamy and Pugh, authors of research into crisis management operations in international relations theory, in regards to their strategy for thinking about peacekeeping, is to divide the field into 'problem-solving' and 'critical' approaches. The 'problem-solving' paradigm accepts that the world order has serious weaknesses, which may at least to a certain extent, be settled conducting peacekeeping operations. In this respect, crisis management operations are understood as efforts taken in order to minimise strain, prevent escalation of conflicts and contribute to such conditions that would enable peaceful settlement of existing or pending conflicts ${ }^{1}$. According to Bellamy, to reach these goals military force may be used, especially if ordinary

\footnotetext{
${ }^{1}$ Gourlay C., "Partners Apart: Enhancing Cooperation between Civil Society and EU Civilian Crisis Management in the Framework of ESDP", 2006. http://www.cmi.fi/files/partners_apart.pdf, 12092007.
} 
instruments of a Westphalian system are incapable to re-establish peace and security in war-torn regions. It is important to mention that according to the 'problem-solving' approach towards peace operations, crises management capabilities may be employed to rebuild liberal-democratic values even without the consent of the host state.

'Critical' theory, on the other hand, advocates a more sceptic approach to crisis management: it attempts to challenge the prevailing world order by analysing the interests it serves for and, ultimately, offers to transform it in a manner that better serves those who are "disadvantaged". Theorists who support this approach see crisis management operations not only in the light of their usefulness in the settlement of particular problems of one or several states: evaluation is given to regional or global importance of the operations as well as conformity of the operations to the requirements of transparency, democracy and accountability. In this context Roland Paris draws a conclusion that other long-term trusteeship strategies may in fact be much more effective than peacekeeping operations.

Statements of Javier Solana, EU High Representative for the Common Foreign Policy, show that the EU tries to combine both 'problem-solving' and 'critical' approaches to the peacekeeping, pace building and long-term ensuring thereof. According to Solana, "the EU implements crisis management operations in response to the UN's call, are taking into consideration the interests of the Member States and the needs of countries exposed to crises. The EU is persistently responding to the changing security situation - even in such cases when doctrines and structures are not yet fully adequate for the achievement of new tasks" ${ }^{\prime 2}$. In other words, missions are started if concrete security related problems should be solved - be it consolidation of rule of law or safeguarding basic human rights. However, this does not mean, that the EU by implementing similar goals always prefers crisis management operations. On the contrary, crises prevention mechanisms, such as EU Special representative institution, neighbourhood policy, membership negotiations, etc. are maybe even more important for the EU security policy. On the other hand, EU 'capacity building' or 'monitoring' operations related to strengthening of mutual trust, establishment of democratic institutions, etc. could also be treated as preventive activity in the field of crises management.

Diplomatic instruments of the EU's external policy are not enlarged in this article. However reasons of intensified EU activities in the field of external relations are worth discussing in more detail. According to Hedley Bull, the development of EU crisis management capabilities is inevitable in view of the vulnerability of Western Europe: at the end of the Cold War, there supposedly were no other possibilities to stop the expansion of the Soviet Union by any

\footnotetext{
${ }^{2}$ Solana J., "Speech by Javier Solana, EU High Representative for the Common Foreign and Security Policy. Graduation Ceremony ESDC High Level Training Course, Stockholm, 17 March 2006”. http://ue.eu. int/ueDocs/cms_Data/docs/pressdata/EN/discours/88870.pdf, 17102007.
} 
other means but developing the crisis management capabilities ${ }^{3}$. Arguments relating to the expansion of democracy, stability and the security zone within and outside Europe are currently prevailing in explanations of EU involvement in the performance of tasks that in fact are attributed to military alliances. On the other hand, threats to security of European countries due to regional conflicts, failing states or proliferation of nuclear weapons in Europe or its neighbouring countries (North Africa, Asian countries) have been relevant for more than several decades. Neither national states, nor acting supranational organisations managed and/or manage to neutralise them, but the EU (or its member states) was not so actively involved in crisis management operations. Therefore, such engagement of the European Union may be explained based not only on liberals' reasoning, but on the arguments of realists as well, i.e., highlighting not the standards of values, but the interests of the EU (or the biggest Member States). In other words, the EU's striving to activate its role in the field of crisis management may be regarded not only as "preventive self-defence", but also as efforts of the biggest Member States to reinforce the status of the EU and their own status as that of "global actors". One more popular form of reasoning in relation to the more active engagement relates to the reinforcement of inner integration within the EU: ESDP is often referenced as the key instrument likely to lead the EU out of crisis ${ }^{4}$.

\section{Classification of EU Crisis Management Operations}

The EU'S responsibility in regard to crisis management is defined by ESDP activity trends defined in Article 17 of the Treaty on the European Union ("Petersberg Tasks") and by the European Security Strategy (ESS). The "Petersberg tasks" provides for EU engagement in peace-keeping tasks, humanitarian and rescue tasks. The European Security Strategy expands the mentioned activities of the European security policy and adds there to joint disarmament operations, the support for third countries in combating terrorism and security sector reform ${ }^{5}$. In November 2006, the EU Council Secretariat published 'Development of European Military Capabilities: The Force Catalogue $2006^{\prime 6}$ portraying five illustrative scenarios to facilitate the use of EU civil and military capabilities: (1) separation of parties by force, (2) stabilisation, reconstruction and military advice to third countries, (3) conflict prevention, (4) evacuation operations, and (5) assistance

\footnotetext{
${ }^{3}$ Bull H., "Civilian power Europe: a contradiction in terms?", Journal of common Market studies 1 (2) 1982-1983 p. 149.

${ }^{4}$ Hettne B., Soderbaum F., "Civilian power or soft imperialism? The EU as a global actor and the role of interregionalism". European foreign affairs review 10 (4) 2005. p. 538

${ }^{5}$ Lindstrom G., "Enter the Battle Groups.“ Chaillot Papers 97, 2007, http://www.iss-eu.org/chaillot/ chai97.pdf, 10112007.

${ }^{6}$ Document drafted considering the force requirement approved in "Headline Goal 2010" in 2004.
} 
to humanitarian operations ${ }^{7}$. This document concluded to describe the scope, where EU military and/or civil instruments may be applied.

During the period of $2006-2007$ around 10,000 EU military and civil officers took part in EU operations. The operations were implemented in Europe, Africa and Asia; they were long-term and short-term, military and civil ones. Civilian crises management operations are divided into capacity building, rule of law and monitoring operations ${ }^{8}$. In most cases the EU implements Capacity Building crisis management operations, i.e., assists local authorities in the training of police officers. In 2004-2005, the EU implemented a Rule of Law mission (EUJUST Themis) in Georgia to assist in the penal system's reform in Georgia. In 2007 the EU started a similar mission in Afghanistan, assisting in the creation of the local police force. The key goal of EU monitoring missions is to monitor the implementation international agreements, control the activities of border-crossing posts. It is worth to mention, that the launching of civilian crisis management operations does not require the approval of the UN Security Council, as these operations do not involve military force (except self-defence). In addition, such missions are usually launched at a request of the host countries themselves.

Military EU operations may be divided into "low-intensity" (implemented absolutely autonomously by the EU) and "high-intensity" operations, which require logistic and military support from the NATO. The EU has completed or has been implementing 5 military operations so far - two in the Balkans (Bosnia \& Herzegovina and Macedonia) and three in Africa (two in Congo and one in Sudan). The planning process of one more massive operation (in Chad and Central African Republic - CAR) was started at the end of 2007. The EU-led missions in the Balkans involved the support from the NATO, while lower-intensity operations in Africa were implemented by the EU autonomously. Table 1 illustrates the characteristics of all EU-led operations carried out in 2006-20079.

\footnotetext{
7 "Development of European Military Capabilities: The Force Catalogue 2006." http://consilium.europa. eu/uedocs/cmsUpload/MilitaryCapabilitiesFC06backgroundNov06_en.pdf, 12092007

8 "EU Missions and operations". IMPETUS. Bulletin of the EU Military Staff. Spring/Summer 2006. p. $8-11$.

${ }^{9}$ The mission in the Former Yugoslav Republic of Macedonia (CONCORDIA) and the mission in the Democratic Republic of Congo (ARTEMIS) were launched and completed in 2003 therefore they are not in the table.
} 

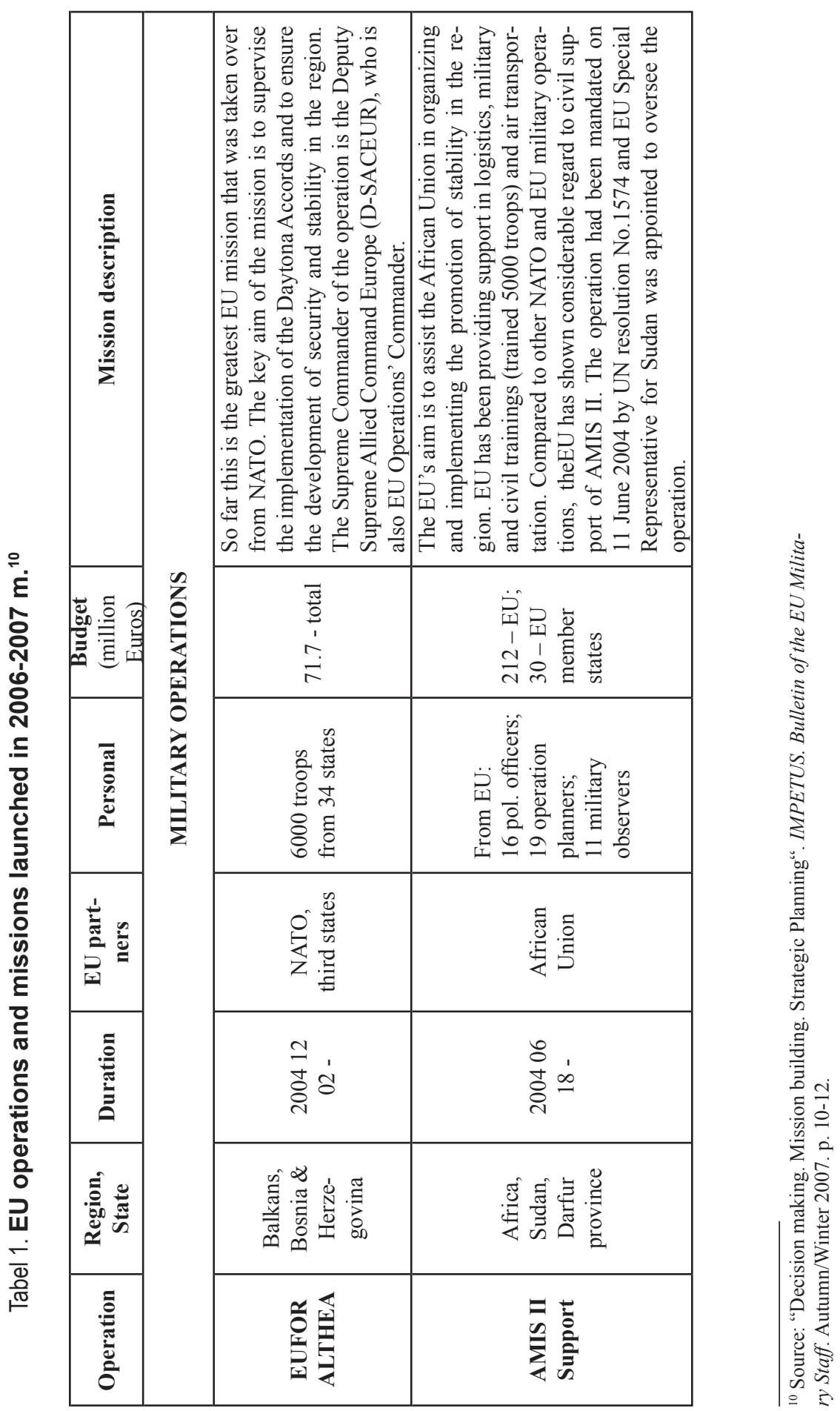


\begin{tabular}{|c|c|c|c|c|}
\hline 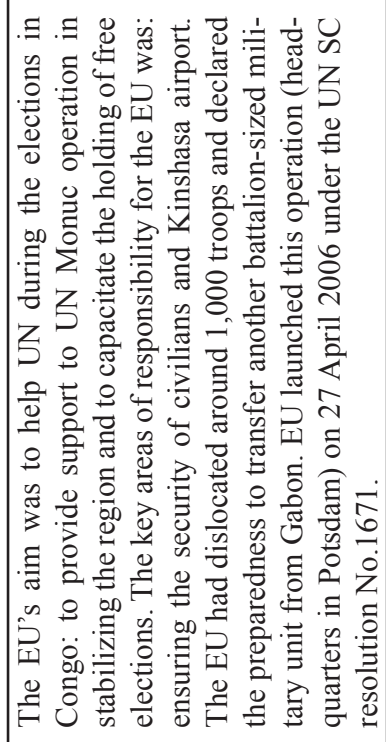 & \multirow{7}{*}{\multicolumn{2}{|c|}{ 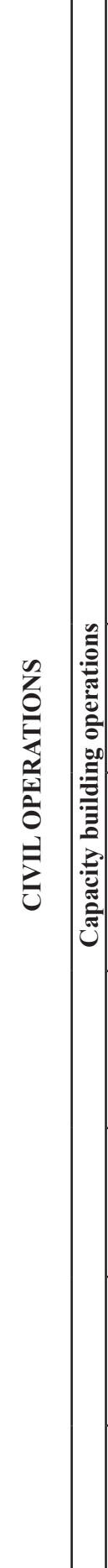 }} & 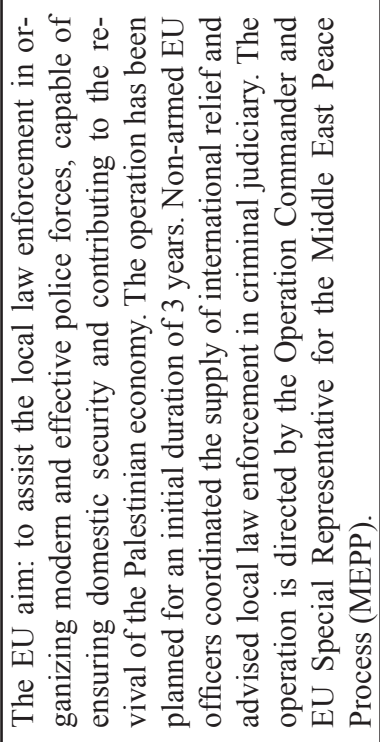 & 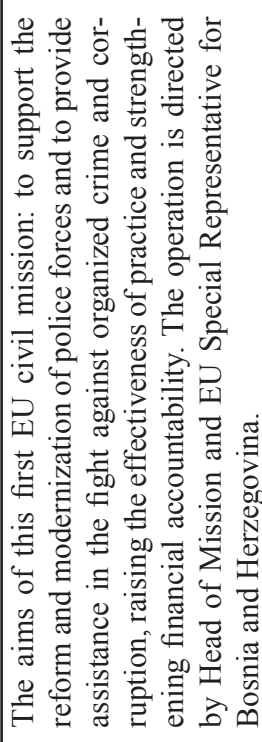 \\
\hline$\hat{\sigma}$ & & & 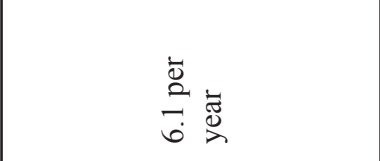 & 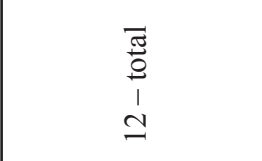 \\
\hline 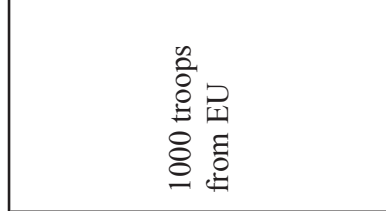 & & & 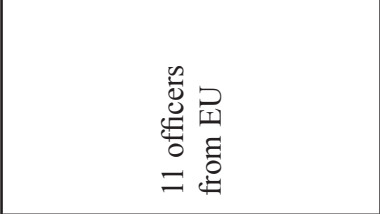 & 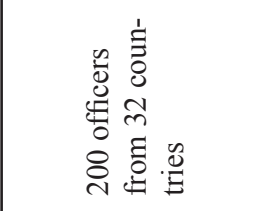 \\
\hline Z & & & ' & 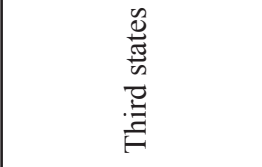 \\
\hline 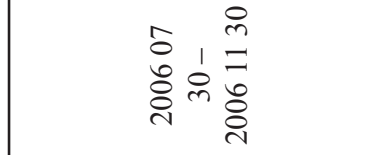 & & & $\begin{array}{l}1 \\
0 \\
\stackrel{1}{0} \\
\text { ¿ }\end{array}$ & $\begin{array}{l}\overline{0} \\
\text { mo } \\
\stackrel{0}{0}\end{array}$ \\
\hline 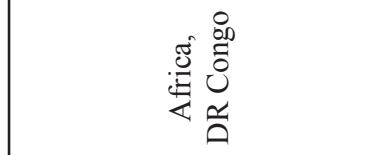 & & & 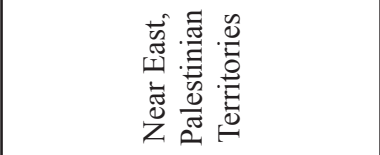 & 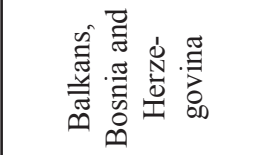 \\
\hline 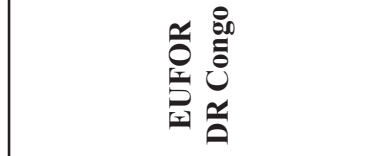 & & & 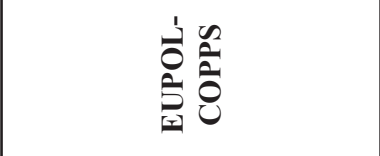 & 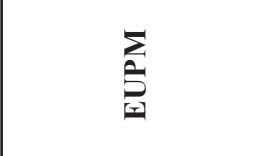 \\
\hline
\end{tabular}




\begin{tabular}{|c|c|c|}
\hline 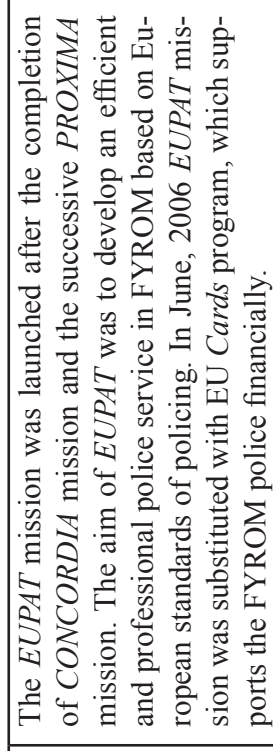 & 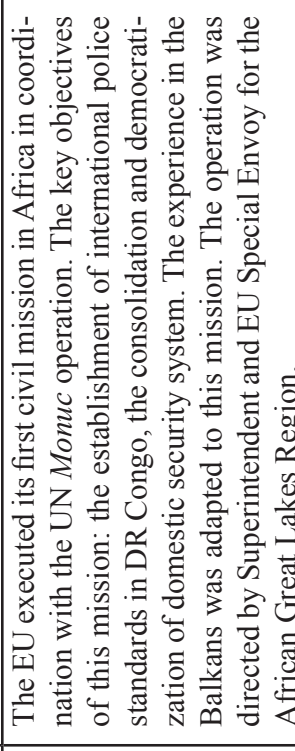 & 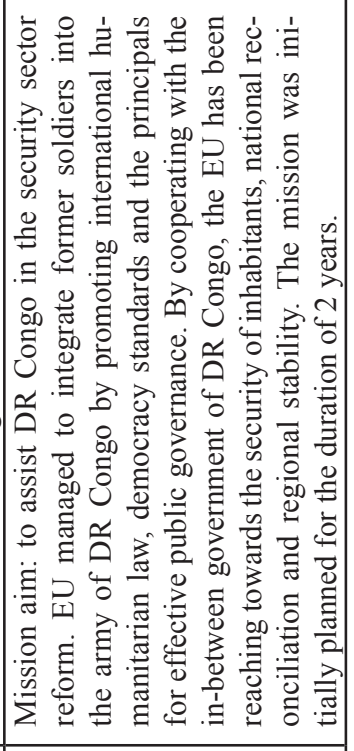 \\
\hline 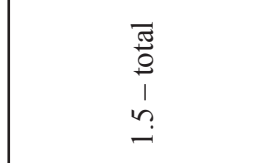 & 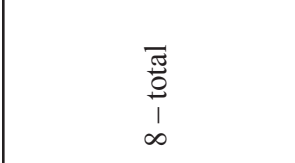 & $\begin{array}{l}\text { 荧 } \\
0 \\
0 \\
1 \\
b\end{array}$ \\
\hline 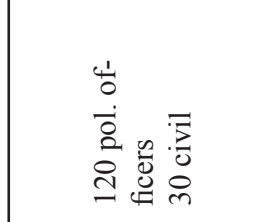 & 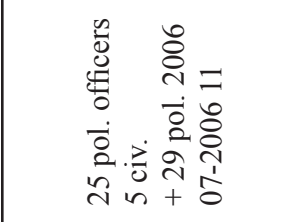 & 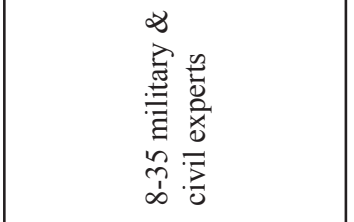 \\
\hline 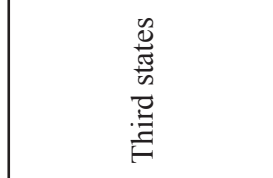 & $z$ & ' \\
\hline 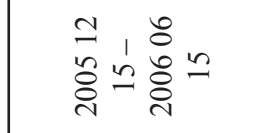 & 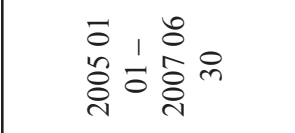 & 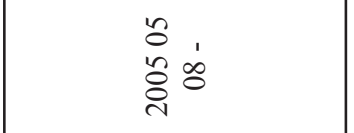 \\
\hline 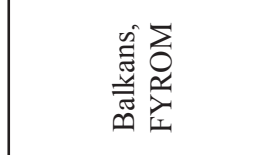 & 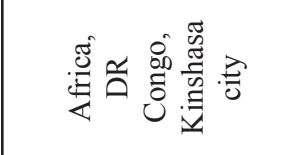 & 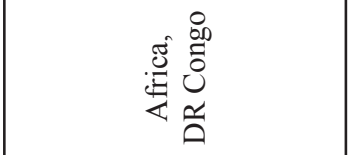 \\
\hline 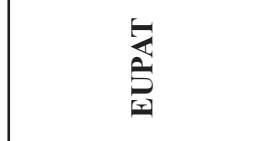 & 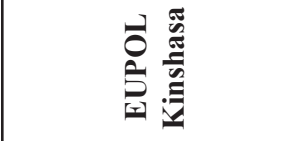 & 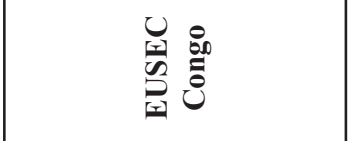 \\
\hline
\end{tabular}




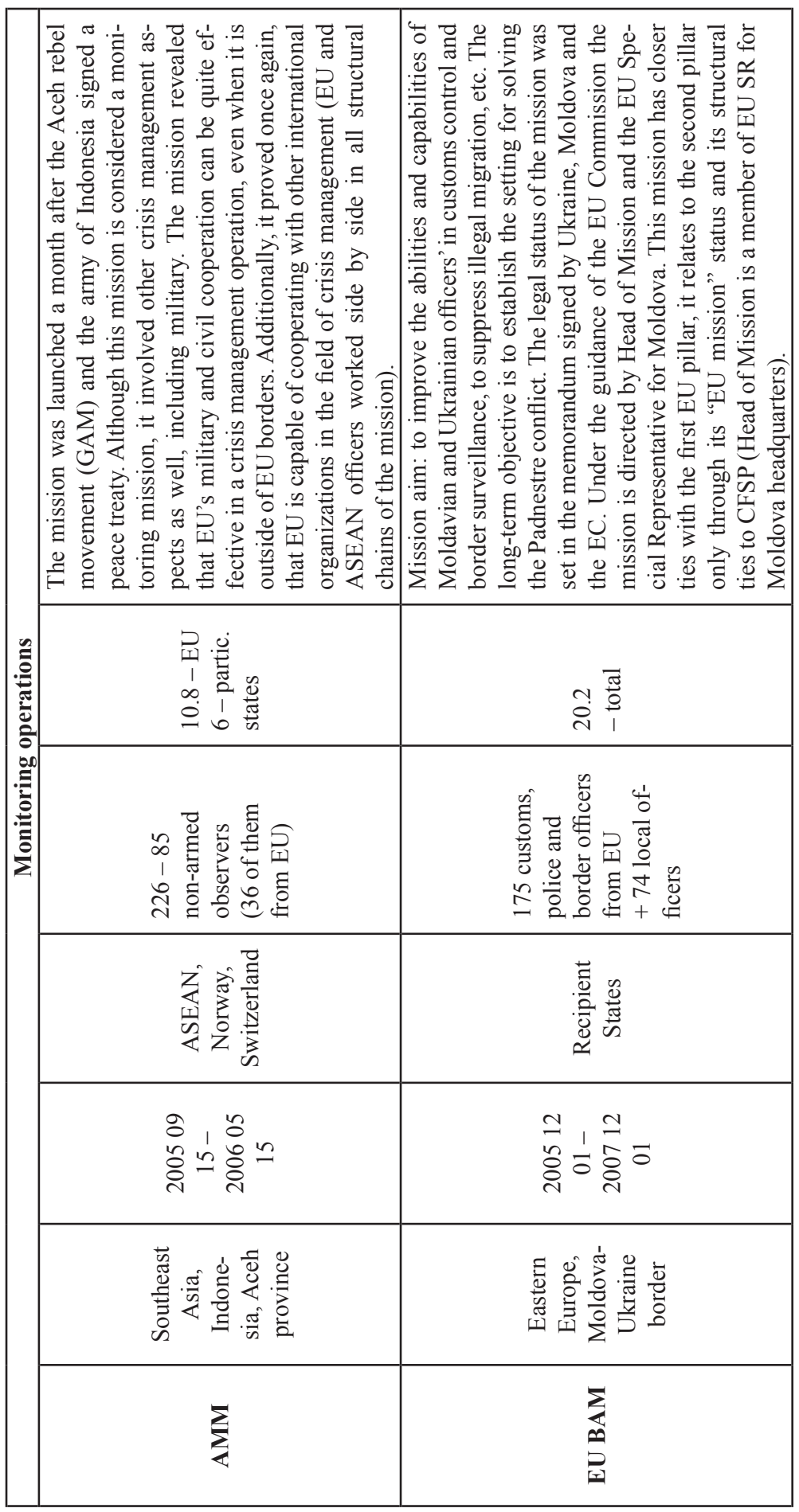




\begin{tabular}{|c|c|c|}
\hline 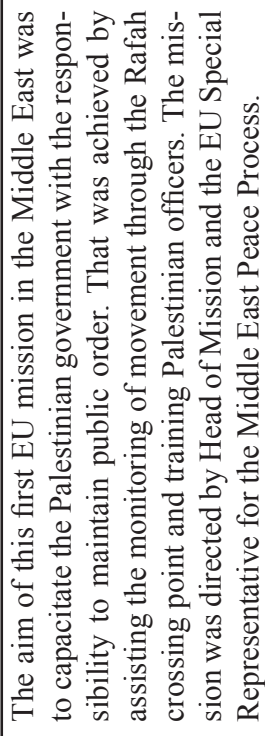 & 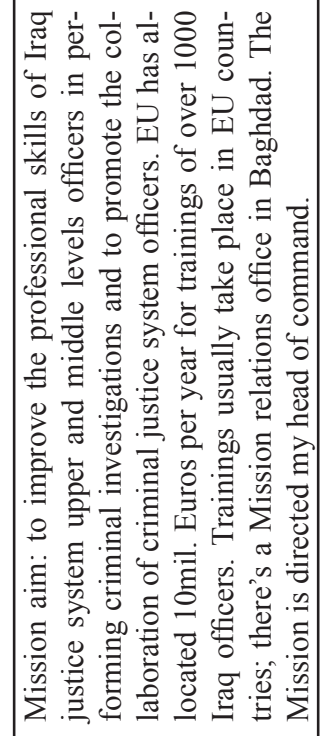 & 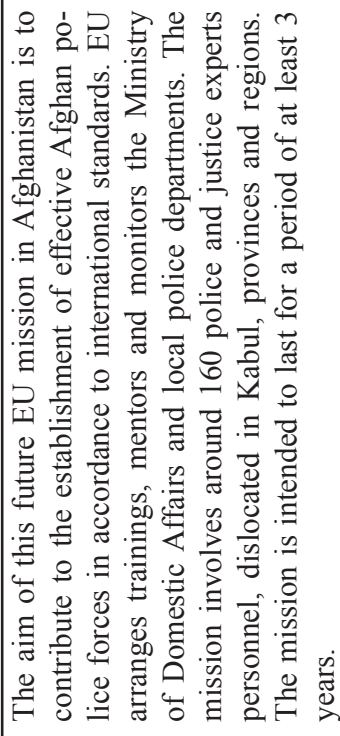 \\
\hline $\begin{array}{l}\frac{\pi}{0} \\
0 \\
1 \\
n \\
=\end{array}$ & 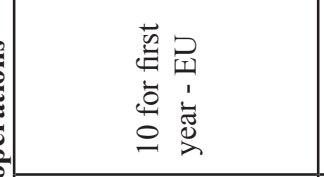 & $\begin{array}{l}\overrightarrow{0} \\
\text { ơ } \\
\dot{q}\end{array}$ \\
\hline 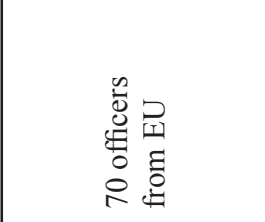 & تُ & 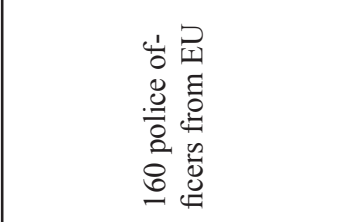 \\
\hline ' & ' & 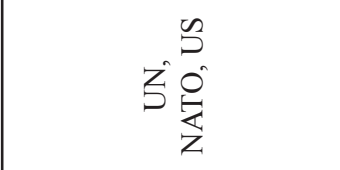 \\
\hline 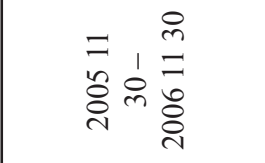 & 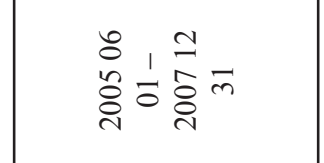 & $\begin{array}{l}1 \\
\stackrel{1}{0} \\
\hat{8} \\
\text { ¿े }\end{array}$ \\
\hline 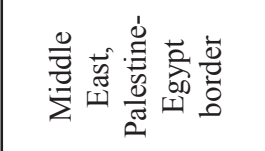 & 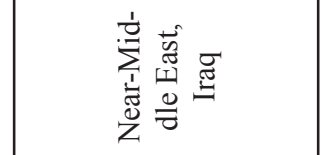 & 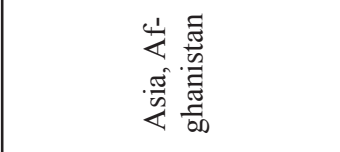 \\
\hline 竞 & 氛量 & 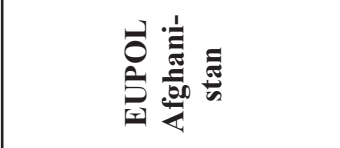 \\
\hline
\end{tabular}




\begin{tabular}{|c|c|c|}
\hline & 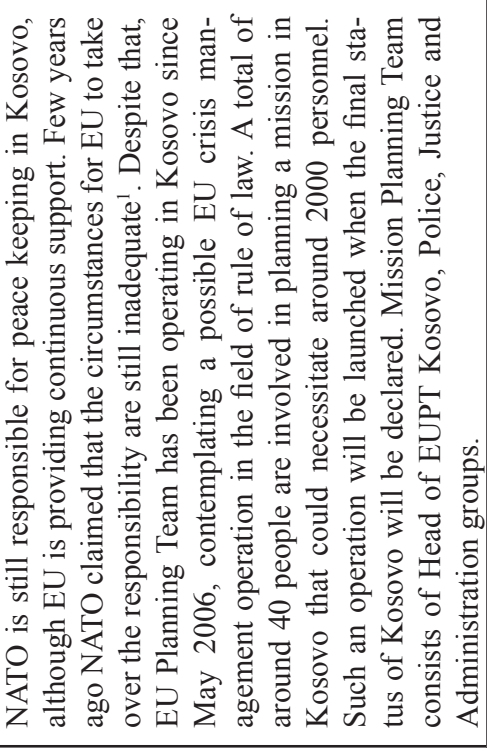 & 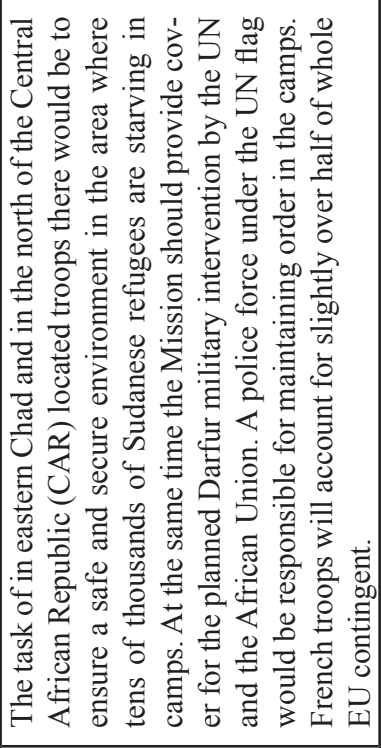 \\
\hline \multirow{6}{*}{ 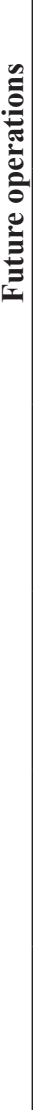 } & $\stackrel{\check{g}}{\ddot{d}}$ & 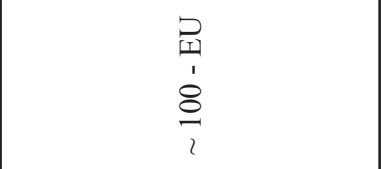 \\
\hline & $\underset{i}{\stackrel{\overbrace{}}{2}}$ & 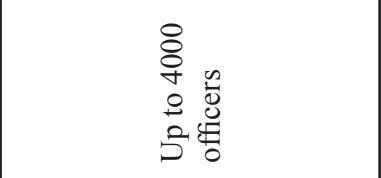 \\
\hline & 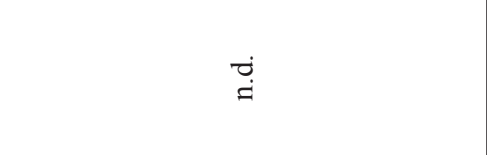 & 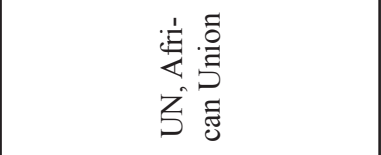 \\
\hline & $\begin{array}{l}1 \\
\stackrel{\infty}{0} \\
\stackrel{2}{1}\end{array}$ & $\stackrel{\infty}{8}$ \\
\hline & 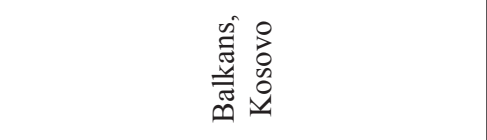 & 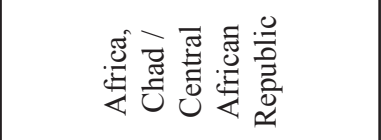 \\
\hline & 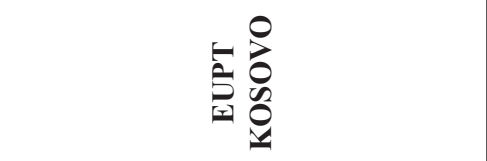 & 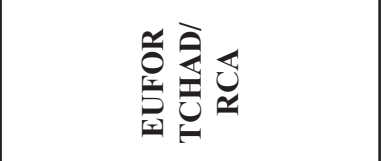 \\
\hline
\end{tabular}




\section{EU choice - Autonomous Civilian and Common Military Operations}

\subsection{EU Motives to Develop Civilian Instruments for Crises Management}

As it can be seen from the data provided above, 17 operations have been initiated within an ESDP framework: 4 of them were of a military nature, 3 were military-civilian, and the other ones were civilian. At the end of 2007 the EU rule of law and police mission in Kosovo (biggest civilian mission ever implemented by the EU) and military operation in Chad/CAR were being planned. Solana has mentioned the possibility to launch a crisis management operation in the regions of "frozen conflicts" in South Caucasus. Presumably, the needs of the region and the EU's prospects to commence new operations there have been analysed by the Solana's office. In parallel, capacities to lead crisis management operations have been strengthened as well: a post of a Civilian Operations Commander has been introduced; and plans to establish headquarters for civilian operations have been developed. In this context the EU theoretically has developed all instruments required for crisis management operations and enshrined a more or less clear scheme for the planning and implementation of (decision making in) crisis management operations (see figure 1). There were no fundamental problems with the financing of civilian missions, which have been normally funded through the EU CFSP budget (separate CFSP budget line provides for EUR 340 million to be assigned by 2013) or by the European Development Fund (EU operations in Africa and the Caribbean countries). Some funds may be assigned by the Member States on the ad hoc basis as well. Therefore some authors argue that in the environment of the increased need for the instruments of civil response there is no other organisation that would be capable of such an effective simultaneous performance of crisis prevention, stoppage of the commenced armed conflicts and stabilisation of post-conflict situations ${ }^{11}$.

\footnotetext{
${ }^{11}$ Cerny P.G, "The new security dilemma: divisibility, defection and disorder in the global era". Review of international Studies, 4, 2000, p. 623
} 


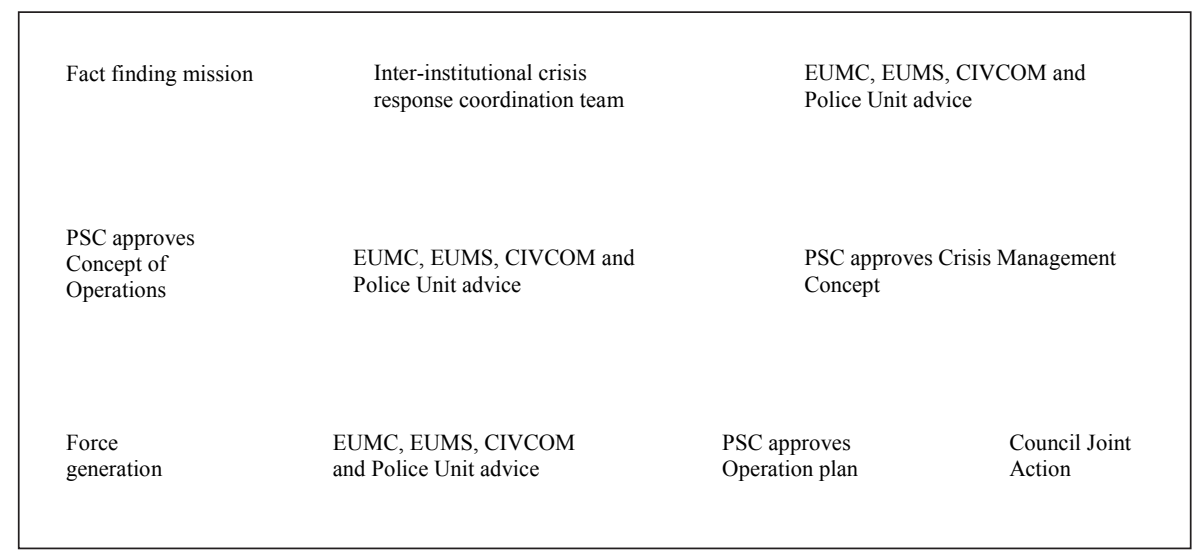

Figure 1. Decision making proces in EU crises managment ${ }^{12}$

Whereas the identification of common EU priorities, as well as the creation of appropriate instruments in the military sphere are not so smooth. In military operations initiative usually belongs not to the supranational EU institutions, but to other subjects of international relations (UN, NATO, African Union), or simply to EU member states. None of EU regional policies could be entitled as coherent, so therefore the use of military instruments usually has only the short term goal in which to stabilize the situation. In other words, it is extremely difficult to identify "common" crises management priorities, which could determine "commitments" of the whole EU regarding one specific region. The results of a lack of a common approach are most obvious then talking about the harmonization of decision making procedures in three EU pillars and the financing of EU military operations:

- In essence member states do not propose any ways for how to coordinate the EU initiatives in the first and second pillars. There is almost nothing done in order to see that more responsibilities are assumed by the EC or more discretion given to coordinate the relations between the EU and other entities engaged in operations is given to EU Special Representatives;

- The funding of military operations is too complicated and not sufficient ${ }^{13}$. The most common principle is that that any country that contributes troops is obliged to pick up all the costs ${ }^{14}$. In case of CONCORDIA and ARTEMIS, ad hoc mechanisms were built to cover common operational costs in order to minimise the costs of the countries directly involved in the operations. After doubts regarding which costs should be attributed to common costs and which to individual ones emerged, the ATHENA mechanism was created for the funding

\footnotetext{
${ }^{12}$ Source: Nowak A., "Civilian crisis management: the EU way" Chaillot Papers 90, 2006, http://www. iss.europa.eu/chaillot/chai90.pdf, 19082007.

${ }^{13}$ According to Article 28 of the Treaty of the European Union, funding of EU crisis management operations depends on the nature of operations, i.e. is it civilian or military.

${ }^{14}$ The so-called "costs lie where they fall" principle.
} 
of subsequent EU military operations. This mechanism provides for allocation of common and individual costs among the Member State according to a gross domestic product scale ${ }^{15}$. In addition, some defence-related authorities (e.g., European Defence Agency, European Institute for Security Studies, European Union Satellite Centre) have their own budgets available for supporting some ESDP initiatives. Some ESDP projects are co-financed by international organisations or private companies together with the EU and the Member States. Such an abundance of mechanisms and procedures sometimes gives rise to long disputes, as to the application thereof. In its turn, this has negative effects on the commencement of operations and is the reason of low effectively thereof.

There are several explanations as to why the EU, seeking for the recognition on international stage, tends to develop civilian rather than military crises management instruments. Some say that open declared values, such as dialogue building, respect to different interests, interregionality, pluralism, democracy, social justice, multilateralism, respect to the international law are still relevant for the EU ${ }^{16}$. This argument is well illustrated by the Force Catalogue 2006: except for 'separation of parties by force', all illustrative scenarios of the use of EU capabilities would require military-civil or merely civil intervention. Other civilian crises management instruments development related arguments may be summarized as following:

- Shortcomings in the field of EU civil crisis management are much less important than institutional and organisational problems in the implementation of military operations:

- The EU has established rapidly deployable civil crisis management capabilities (IPU, FPU, CRTs ${ }^{17}$ );

- Decision making and mobilisation of resources for civilian operations are quite expeditious (as proved by EU-led mission Artemis, AMM, EUBAM Rafah);

- Experts from the Member States participating in civil crisis management operations are probably the best qualified in this area;

\footnotetext{
${ }^{15}$ It seems that application of this mechanism will be extended: on February 2007, the European Council resolved to extend the scope of application of this mechanism by covering such fields as maintenance of the EU operational headquarters staff at the place of dislocation, data acquisition, acquisition of incidental means, security of static forces, etc.

Bendiek A., Whitney-Steele H., "Financing of EU's CFSP. Solving the Conundrum". SWP Comments 2006. http://www.swp-berlin.org/en/common/get_document.php?id=1726, 12102007

${ }^{16}$ On the other hand, according to Robert Kagan, this choice is not coincidental: it is the natural choice of the weak and is opposite to American "real world" of Thomas Hobbes. According to Kagan, emphasising EU normative power does not contradict arguments as to the "weakness" of military power that determines the EU strategy - civil power is the only instrument available for weaker Europe.

Hettne B., Soderbaum F., "Civilian power or soft imperialism? The EU as a global actor and the role of interregionalism". European foreign affairs review 10 (4), 2005, p. 538.

${ }^{17}$ IPU (Integrated Police Units) and FPU (Formed Police Units) - rapidly (up to 30 days) deployable police forces capable of performing police functions of whatsoever types. CRTs (Civilian Response Teams) - pre-identified and trained experts, deployable in 5 days, assigned to data collection or similar missions.
} 
- The development of military instruments in an ESDP framework may constitute duplication and weakening of NATO, the primary instrument for the implementation of USA interests in the European security system. According to Hans Christian Hagman, that's why the USA prefers the support to the EU's development civilian instruments rather than military ones (NATO planners shared in the drafting of the mentioned illustrative scenarios for EU crisis management operations). Therefore, most of the USA's allies in Europe support the development of the ESDP's civilian dimension and thus define the nature of the operations;

- The EU avoids launching such operations, which success is not guaranteed and failure of EU-led military operations is much more probable than that of civilians. Therefore, the EU is not capable of autonomous acting in performance of military crisis management operations (logistic support from NATO is necessary). In addition, most Member States prefer military acts to be based on relevant UNSC resolutions;

- The Member States are not willing to increase funding assigned to the defence sector. Therefore, the EU cannot afford (or avoids) engagement in expensive, high-intensity operations.

\subsection{EU Cooperation with NATO, the UN and the African Union in the Field of Military Crises Management}

In the field of military crises management, the EU in most cases has tended to adjoin other organisations already operating in this area. The EU would assume responsibility either by replacing these organisations on the scene of crisis or by adding to their activities. Partners - both national and international organisations - have been invited to join nearly all missions and operations initiated by the EU itself ${ }^{18}$. The EU is not yet ready to act autonomously in "highintensity" operations, and this is determined by shortcomings in operation planning, managing, monitoring and implementation components. In its turn, this determines active cooperation of the EU with the NATO, UN, AU (African Union) and other entities of international relations in the implementation of military crisis management operations.

\subsubsection{EU-NATO Cooperation}

The first agreements (the so-called Berlin agreements) on the USAEuropean cooperation in European autonomy-building in the field of crisis management were signed in 1994-1996, when it became clear that the USA is shifting their attention from Europe and its neighbouring countries to Asia.

\footnotetext{
${ }^{18}$ There have been very few operations carried out by the EU independently, and these operations involved up to 100 officers.
} 
Yet, conceptualisation of EU crisis planning, implementation and management operations independently from the NATO and fundamental review of EUNATO relations took place as late as in 1998-2003. First EU-NATO agreements were signed in Washington in 1999, but in 2002 it started getting evident that autonomy in decision making and repute of both organisations are of no less importance for them than the technical nature of this cooperation. Durring March 2003, the then NATO Secretary-General Lord George Robertson and the EU security policy chief Javier Solana signed agreements (also known as "Berlin plus" agreements) which defined NATO and EU relations more particularly. Though reiterating some details of the 1996 agreements (for example, that the EU is free to use NATO planning and management resources for crisis management operations), these agreements provided the EU with access to NATO intelligence information.

Nonetheless, "Berlin plus" agreements do not constitute official and binding agreements between two institutions and are based on a non-binding EUNATO declaration which is not an international treaty, either. Accordingly, in order to enable the EU to use NATO resources, "Berlin plus" must be elaborated on by other supplementary agreements. They might be blocked up by some NATO, but not EU, members (for example, Turkey) due to the peculiarities of the national policy (such as relations with Cyprus and Malta). In other words, the availability of NATO resources for the EU depends on a particular case, as the NATO is not unconditionally obligated under "Berlin plus" to let use its resources or, even more so, to transfer some particular capacities. In addition, NATO as an organisation does not dispose of a lot of such resources, and "Berlin plus" agreements do not give the EU the opportunity to use US resources. After the signing of the agreements in 2003 it even became unclear whether NATO still exercises the right of first refusal: according to some EU countries, a decision as to the engagement is taken not by an organisation, but by the Members States ${ }^{19}$, so it is for the Member States, not NATO, to decide which organisation shall take part in one or another operation (unilateral decision of the Member States is required in any case). Therefore, the EU-NATO cooperation under "Berlin plus" agreements is not as clear as it may look like.

It is obvious that "Berlin plus" agreements will be effective as much as EU and NATO countries will be interested in the implementation thereof. In the summer of 2003 both organisations agreed on a "concerted approach" to the West Balkans and the EU took over NATO-led operations in Bosnia and Macedonia. It's worth noting, however, that neither CONCORDIA in Macedonia nor EUFOR ALTHEA in Bosnia and Herzegovina are such the type of operations that might be expected bearing in mind EU ambitions and the sense of the above-mentioned agreements ${ }^{20}$. The point is that NATO has stayed on in both countries: about 300 military men led by a US commander are foreseen in NATO reserves in case the situation in Bosnia suddenly gets complicated.

\footnotetext{
${ }^{19}$ Touzovskaia N., "EU-NATO relations". European security 15 (3), 2006, p. 242.

${ }^{20}$ Truth to say that CONCORDIA was commenced prior to signing "Berlin plus" agreements.
} 
NATO has also retained a headquarters staff in Sarajevo, which, truth to say, is mainly engaged in activities related to NATO PfP programme and support in the field of defence reforms. EUFOR ALTHEA operation was planned at NATO command post. The EU operational headquarters staff, are located here too. The operation is led from NATO Allied Joint Force Command Naples. NATO's Deputy Supreme Allied Commander is also a EUFOR Operational Commander. Therefore, one cannot say that NATO has withdrawn from the mentioned states and the Alliance has been replaced with the EU, which is only using some NATO capabilities. On the other hand, the political control of the operation is vested upon the EU which defines their strategic guidelines of the operation and retains autonomy in decision making in this area.

Accordingly, the EU and NATO cooperation may be seen in two lights. On the one hand, both organisations cooperate in the implementation of allied operation within and outside Europe (for example, EU/NATO headquarters has been established in Addis Ababa where, according to diplomats, NATOEU cooperation is very tight). In cooperation with NATO, the EU significantly contributed to the creation of security and stability in Macedonia and proved being able to alter the nature of its intervention subject to the needs of the host country. On the other hand, despite such cooperation, the mentioned two organisations have not managed to settle the sorest problems (the situation in Darfur has been getting worse over the latter years despite joint NATOEU activities in the region) or, at least, to agree on the quantity and quality of forces needed for the regulation of the conflict. In addition, irrespective of political declarations, the EU and NATO have been ineffectively duplicating each other's capabilities and even competing in political area. This was also stressed by NATO Secretary General Jaap de Hoop Scheffer with regard to the necessity of closer cooperation between NATO and the EU "we are working past each other. It means that we are duplicating each other's efforts. And that we are wasting taxpayers' money"21.

\subsubsection{EU-UN Cooperation}

The EU launches military operations only subject to the UN's approval or after adoption of a relevant resolution by the UNSC, even if such resolution is not necessarily required by the nature of the operation. The EU and the UN cooperation in joint crisis management operations is no less important. For example, the essence of operation ARTEMIS, an EU-led mission in Congo from June - September 2003, consisted in the support to MONUC, a United Nations mission in the Democratic Republic of Congo. In order to secure peace and prevent humanitarian catastrophe, the EU (mainly France) sent 1,500 military men in 2003 to contribute functionally to MONUC forces. This first EU-led

21 "EU Civilian - Military Supporting Action to the AMIS II Mission in Darfur", 2004, Media Briefing of the Council of the European Union. http://ue.eu.int/Newsroom. 08252007 
initiative in Africa was important in terms of both crisis management and prevention: after the withdrawal of Uganda military troops, there appeared a "security vacuum" in the region and mass disturbances started in the Ituri region of Congo. The UN mission was incapable of suppressing them, while EU forces created conditions for refugees to come back to Bunia and provided them with shelter until MONUC forces were back in the town. Though the mandate of operation EUFOR RD Congo in 2006 was different, the mission also aimed at supporting MONUC during parliamentary and presidential elections. Engagement in this operation transformed the reputation of the EU as an international actor incompetent neither to agree nor to carry out complicated crisis management operations. Moreover, the EU support and experience helped the UN Organisation to rearrange MONUC by extending the operation geographically and granting it mandates to employ military force when necessary. In addition, this significantly reinforced the image of the EU as a effective crisis management actor. It is also important that the successful course and finale of the operation ARTEMIS (for which neither the EU nor the UN used any logistic support from NATO) served as a basis for the development of the EU Battle Groups Concept: security policy in HEADLINE GOAL 2010 sets forth that Battle Groups will be formed from 1,500 soldiers, their training period will be 10 days and these single sets will be available for the implementation of fast UN intervention responses. Finally, successful EU-UN cooperation in Africa demonstrated what "effective multilateralism" is. This term was thereafter used in the European Security Strategy. To summarise, we can say that cooperation with the UN is important to the EU for the following reasons: a) the need to legitimate operations in the eyes of international community; $b$ ) striving to extend the geography of EU operations territories far away from Europe (formation of the identity of a global actor) c) aspiration to demonstrate that despite of resource generation difficulties the EU is capable of performing successful operations without NATO support.

\subsubsection{EU-AU Cooperation}

In Sudan, the African Union peace agreement monitoring mission Amis II was taken over by the EU by establishing there components of military and civilian operations. This operation differed from other EU-led military intervention operations in that it was aimed at support to the African Union, i.e., training it how to plan and implement crisis management operations. The EU provided the African Union with financial and other resources by training military supervisors and offering strategic transport. In other words, the subject matter of the operation was not the support to a particular country to solidify peace and security thereat, but support to another international organization engaged with such mission. That's how the EU attempted to create a new crisis management precedent where support is being rendered to a regional organisation operating in its "own territory", subject to recognising UN's supremacy 
in decision making as to the involvement in the operation and leaderships (the African Union acted in Sudan in accordance with UNSC resolution).

The EU's involvement in Amis II proved the above-mentioned EU's disposition to seek for autonomy from NATO and act in close cooperation with the UN Organisation. Even if it wanted to, the EU was unable to launch the operation in Sudan autonomously due to the shortage of capabilities and lack of preparation. Being engaged with complicated operations in Iraq and Afghanistan, after a painful experience in Africa, the USA did not even consider a possibility to get engaged in peace building in Sudan. Possibilities to implement the operation using joint EU and NATO leadership and planning capabilities were considered and eventually rejected by NATO and EU military committees. Many NATO and EU members have been trying to decide for a long time, which organisation to support: the UK, Italy and the Netherlands decided to offer strategic transport capabilities to NATO, while Greece, Germany and France preferred not going outside the EU boundaries. NATO and EU officers have been discussing the issue on the support to the African Union more than a month in Brussels. One more month passed before they reached an agreement as to the coordination of actions by the organisations. And even after all decisions were made, implementation thereof was delayed again, as France did not agree to act in a NATO framework and provide with strategic air transport capabilities through SHAPE structures.

EU-AU cooperation in crisis management operations in Africa is not a coincidence. One should remember that the Action Plan on the ESDP support to the fortification of peace and security in Africa was developed by the European Council as early as in 2004, i.e., right after active development of the ESDP itself was commenced. One of the most effective CFSP instruments - the appointment of an EU Special Representative - was also first tried by the EU in the African Great Lakes Region as early as in 1996. In other words, the EU Special Representative has been taking care of peacekeeping and peacebuilding in Africa for more than 10 years by making political declarations and initiating, on behalf of the EU, political pressure on the defaulting parties to the conflict. These actions were not enough to stop conflict rising in Rwanda and Burundi, but in Congo actions of the EU Special Representative were quite effective in preventing political crises (usually constituting a precondition for armed conflicts). 


\section{Conclusions}

There are no obligatory conditions or rules set as to when and how the EU should engage in or initiate crisis management operations or missions. There neither is any clearly defined system of assigning capabilities for EU operations. Except for assigning forces to EU Battle Groups, the Member States are free to decide how many capabilities they shall assign subject to available resources. Despite this, ESDP operations should not be undervalued. The first crisis management operations were launched as late as in 2003 and may be still qualified as preparations for the further development of the ESDP. However, results of such operations are quite palpable.

After a few years from the creation of the EU Common Security Policy and commencement of crisis management operations, one trend is clearly identifiable: the EU mainly focuses on civil or civil-military crisis management instruments. This is determined by the structural organisation of the EU and approach of the Member States towards crisis management: as early as in 2004, at the Civilian Capability Commitment Conference, EU Member States volunteered 5,761 police personnel, 631 rule of law experts, 562 civilian administration experts, and 4,988 individuals for civil protection functions. However, operational availability of Battle Groups was reported as late as in the beginning of 2007. In addition, after all EU-launched initiatives in 2005, one can boldly say that Africa is in the focus of EU crisis management operations: European countries not only deploy the biggest peace building forces in this continent, but also are the major donors and trade partners of Africa. Finally, the review of the preconditions of operations, and the operations themselves, implemented by the EU in 2006-2007 lead to the following conclusions:

- Though EU initiatives in the field of crisis management are not always effective, the EU is able to use of its experience in developing new response instruments to challenges. For example, the EU used full potential of its institutional organisation during its operations in Congo: to fortify democratisation in Congo in short-term and medium perspectives, civil and military crisis management instruments have been used, to achieve long-term goals humanitarian aid and development projects have been commenced, support to NGOs in the regions have been provided from the EC budget ${ }^{22}$.

- There is quite a large variety of instruments available for the EU in the field of security policy. EU operations in Africa have proved that combinations of EU initiatives in the first and second pillars enable not only more rapid training of officers required for a mission, but also using the principle of "carrots and sticks" in the most effective way: only when conflict prevention indicators were included in the Country Strategy Papers by the EC Directorate General

\footnotetext{
${ }^{22}$ Martinelli M., "Helping Transition: the EU Police Mission in the Democratic Republic of Congo (EUPOL Kinshasa) in the Framework of EU Policies in the Great Lakes". European Foreign Affairs Review 11, 2006. p. 380.
} 
for Development, African authorities understood that no financial support and humanitarian aid would be received unless they implement conflict prevention and reduction measures ${ }^{23}$;

- The EU is capable of coordinating its activities with NATO and the UN. Experience in the Balkans and Congo shows that the EU is capable of implementing missions autonomously or in cooperation with other organisations; it may contribute to operations carried out by other organisations or take over mission leadership from other international organisations;

- It is necessary to create a simpler and more flexible mechanism for the funding of EU military operations (funding of civilian operations in this regard is comparatively effective). Some efforts to tackle problems in this area are already taken: debates are in progress for approving 1 per cent of all funds foreseen for EU external policy to finance ESDP initiative in future. This would amount to approximately EUR 5 billion between 2006 - 2013.

- EU faces some institutional and organisations difficulties in the implementation of crisis management operations. Experience shows that the EU should be able to commence the planned mission in shorter time: this is possible by entering into ad hoc international agreements with third parties willing to contribute and thus attracting additional financial resources;

- The EU should improve the cooperation between civil and military components of operations, both in case when military EU operations are replaced with civil ones (in Macedonia), and when military and civilian instruments are used in parallel (support to $A M I S I I$ ). This would accelerate the commencement of the operations and contribute to the achievement of long-term objectives thereof.

\section{Literature}

\section{Documents}

"Development of European Military Capabilities: The Force Catalogue 2006." http:// consilium.europa.eu/uedocs/cmsUpload/MilitaryCapabilitiesFC06backgroundNov06_ en.pdf, 12092007

\section{Oficial statements, speeches, interview}

1. "EU Civilian - Military Supporting Action to the AMIS II Mission in Darfur", 2004, Media Briefing of the Council of the European Union. http://ue.eu.int/Newsroom. 08252007

2. Solana J., "Speech by Javier Solana, EU High Representative for the Common Foreign and Security Policy. Graduation Ceremony ESDC High Level Training Course, Stockholm, 17 March 2006" http://ue.eu.int/ueDocs/cms_Data/docs/pressdata/EN/discours/88870.pdf, 17102007.

\footnotetext{
${ }^{23}$ This Strategy is effective to a great extent due to that the European Union has been the major donor for African countries for a long time. In other words, in case of Europe's withdrawal from this continent, African states would be abandoned by the most important and probably the sole donor. The absence of alternatives is a highly important reason making African governments implement European requirements to be eligible for support.
} 
Research

Gourlay C., "Partners Apart: Enhancing Cooperation between Civil Society and EU Civilian Crisis Management in the Framework of ESDP", 2006. http://www.cmi. fi/files/partners_apart.pdf, 12092007.

\section{Academic Articles}

1. Bull H., "Civilian power Europe: a contradiction in terms?", Journal of common Market studies 1 (2) 1982-1983

2. Cerny P.G, "The new security dilemma: divisibility, defection and disorder in the global era“. Review of international Studies, 4, 2000.

3. EU Institute for Security studies, "EU Security and Defence. Core documents". Chaillot papers 75, 2005.

4. Hettne B., Soderbaum F., "Civilian power or soft imperialism? The EU as a global actor and the role of interregionalism". European foreign affairs review 10 (4) 2005.

5. Lindstrom G., "Enter the Battle Groups.“" Chaillot Papers 97, 2007, http://www.isseu.org/chaillot/chai97.pdf, 10112007.

6. Martinelli M., "Helping Transition: the EU Police Mission in the Democratic Republic of Congo (EUPOL Kinshasa) in the Framework of EU Policies in the Great Lakes“. European Foreign Affairs Review 11, 2006.

7. Nowak A., "Civilian crisis management: the EU way" Chaillot Papers 90, 2006, http://www.iss.europa.eu/chaillot/chai90.pdf, 19082007.

8. Touzovskaia N., "EU-NATO relations". European security 15 (3), 2006.

\section{Articles, reports}

1. Bendiek A., Whitney-Steele H., "Financing of EU's CFSP. Solving the Conundrum“. SWP Comments 2006. http://www.swp-berlin.org/en/common/get_document. php?id=1726, 12102007

2. "Decision making. Mission building. Strategic Planning". IMPETUS. Bulletin of the EU Military Staff. Autumn/Winter 2007..

3. "EU Missions and operations". IMPETUS. Bulletin of the EU Military Staff. Spring/ Summer 2006. 